\title{
Analisis Keakuratan Arah Kiblat Masjid di Kecamatan Tanete Riattang Barat Kabupaten Bone
}

\author{
Andi Jusran Kasim ${ }^{1}$ \\ STAIN Majene Jl. BLK Kec. Banggae Kab. Majene, Sulbar \\ Email:1jusrankasim@stainmajene.ac.id
}

\begin{abstract}
This article examines and tests the accuracy of the direction of several mosques in Tanete Riattang Barat by using several methods, namely the Qibla azimuth method, Google Earth satellite imagery and using istiwa sticks. In this study, the author describe several mosques as samples and test the accuracy level of Qibla direction, where some people consider the issue of Qibla direction to be a classic problem. But in fact, this problem is still discussed and sometimes controversial. There are parties who agreed, some refused. It is important to note that the Qibla direction is the closest direction to the Ka'bah (Masjid al-Haram) through the great circle of the Earth, the direction where people want to pray so that the direction cannot be considered trivial or even insignificant, which can potentially cause conflict in community. For this reason, the determination of Qibla direction must be correct so that the perfection of worship can be achieved, thus minimizing the potential for conflict of understanding.
\end{abstract}

Keywords : Qibla Direction; Azimuth Qibla; Google Earth; Istiwa Stick.

\begin{abstract}
Abstrak
Artikel ini mengkaji dan menguji keakuratan arah beberapa masjid di Tanete Riattang Barat dengan menggunakan beberapa metode, yaitu metode azimuth kiblat, pencitraan satelit Google Earth dan menggunakan tongkat istiwa. Dalam penelitian ini, penulis menggambarkan beberapa masjid sebagai sampel dan menguji tingkat akurasi arah kiblat, di mana beberapa orang menganggap masalah arah kiblat sebagai masalah klasik. Namun faktanya, masalah ini masih dibahas dan terkadang kontroversial. Ada pihak yang setuju, ada yang menolak. Penting untuk dicatat bahwa arah kiblat adalah arah terdekat ke Ka'bah (Masjid al-Haram) melalui lingkaran besar Bumi, arah di mana orang ingin sholat sehingga arah itu tidak dapat dianggap sepele atau bahkan tidak signifikan, yang berpotensi menyebabkan konflik di masyarakat. Untuk alasan ini, penentuan arah kiblat harus benar sehingga kesempurnaan ibadah dapat dicapai, sehingga meminimalkan potensi konflik pemahaman.
\end{abstract}

Kata Kunci: Arah Kiblat; Azimuth Kiblat; Google Earth; Tongkat Istiwa. 


\section{Pendahuluan}

Agama Islam adalah agama yang senantiasa memberikan keringanan bagi umatnya. Sebagai contoh, orang Islam yang akan melaksanakan ibadah salat padahal kondisi fisiknya sedang sakit, Islam memberikan keringanan dengan melaksanakan salat sesuai dengan kemampuannya. ${ }^{1}$

Salat adalah tiang agama, ibarat sebuah rumah apabila tiang-tiangnya tidak berdiri dengan kokoh sudah barang tentulah rumah itu akan roboh, demikian halnya dengan agama seorang muslim akan roboh apabila salat tidak pernah dilakasanakan. Mengerjakan salat bisa dimana saja, di masjid, mushollah, dan tempat-tempat lain yang suci dari najis dan kotoran.

Kemegahan sebuah masjid maupun keindahannya bukanlah prioritas utama, yang terpenting adalah masjid tersebut harus tepat mengarah ke kiblat (Masjidil Haram $)^{2}$. Mendengar kata kiblat sudah barang tentulah timbul pertanyaan, apakah arah masjid saat ini telah mengarah kepada arah sebenarnya yaitu arah kiblat, Sebagaimana kesepakatan para ulama bahwa menghadap ke arah kiblat merupakan salah satu syarat sah salat. ${ }^{3}$

Sangat memungkinkan arah kiblat tiap masjid berbeda satu sama lain, sebab banyak diantara masjid yang mempunyai bangunan yang cukup tua, sehingga dengan perkembangan ilmu pengetahuan khususnya ilmu falak, ${ }^{4}$ penetuan arah kiblat dapat dengan mudah diketahui perbedaan arah kiblat masjid tersebut.

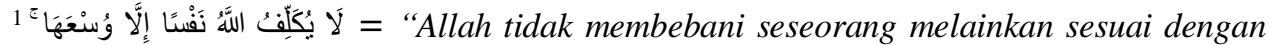
kesanggupannya”. Terjemahan tafsir kandungan potongan ayat surah Surat Al-Baqarah Ayat 286 yaitu: Ajaran agama Allah itu mudah, tidak ada unsure kesulitan di dalamnya. Allah tidak menuntut dari hamba-hambanya sesuatu yang tidak mereka sanggupi .https://tafsirweb.com/1052 surat-al-baqarah-ayat-286.html diakses tanggal 1 Juli 2019.

${ }^{2}$ Lihat QS. Al-Baqarah/2:144.

${ }^{3}$ IbnuRusyd al-Qurtuby, Bidayat al-Mujtahid wa Nihayat al-Muqtashid (Beirut: Dar alFikri, tt.), I: h.80.

${ }^{4}$ Ilmu Falak 'Amaliya dalam ilmu falak seperti yang dikenal masyarakat umum di negeri ini sebagai ilmu hisab, yaitu ilmu yang memanfaatkan hasil-hasil penyelidikan tentang pola gerakan benda-benda langit, khususnya Bumi, Bulan, dan Matahari untuk kepentingan praktis, seperti untuk menghitung tibanya waktu-waktu salat, saat kemunculan Hilal untuk acuan penentuan awal bulan kamariah, sudut arah kiblat, dan sebagainya. Lihat: Abd. Salam, Ilmu Falak Praktis (Waktu Salat, Arah Kiblat, dan Kalender Hijriah), (Buku Perkuliahan Program Sarjana Studi Hukum Ekonomi Syari'ah (Muamalah) Fakultas Syari'ah dan Hukum UIN Sunan Ampel Surabaya, 2007), h. 6. 
Kekosongan peraturan perundang-undangan ${ }^{5}$ yang semestinya mengatur pelaksanaan pengukuran arah kiblat, menjadi salah satu sebab masyarakat belum tahu siapa yang berwenang melakukan hal tersebut. Ada kecenderungan masyarakat untuk menyerahkan masalah penentuan arah kiblat ini sepenuhnya kepada tokoh-tokoh dari kalangan mereka sendiri, sehingga apa yang diputuskan oleh tokoh tersebut itulah yang diikuti, walaupun di kemudian hari diketahui bahwa penentuan arah kiblatnya kurang tepat.

Banyak terjadi pada kelompok masyarakat yang mempunyai pemikiran belum begitu terbuka, tentu saja hal ini bisa menimbulkan keresahan di kalangan umat Islam Indonesia karena masalah kiblat merupakan hal yang sangat urgen bagi pelaksanaan ibadah umat Islam. Keadaan seperti ini sudah barang tentu kita akan mengalami kesulitan tanpa mengadakan pendekatan dengan tokoh tersebut, sekalipun dalam penentuan arah kiblat, dengan begitu hasil pemikiran yang kita peroleh akan menjadi sia-sia. ${ }^{6}$

Kiblat $^{7}$ adalah arah dalam ibadah salat, yang bertujuan menyatukan umat Islam, maka dari itu sudah sepatutnya umat Islam berusaha untuk menciptakan keseragaman arah dalam beribadah. Terutama di tempat ibadah seperti masjid dan mushollah. Sehingga keutamaan amal dalam beribadah serta kesempurnaan ibadah dapat tercipta.

Penelitian ini akan mendeskripsikan sejarah singkat penentuan arah kiblat masjid-masjid di Kecamatan Tanete Riattang, dan bagaimana tingkat keakuratan arah kiblat masjid-masjid di Kecamatan Tanete Riattang Barat, Kabupaten Bone.

\footnotetext{
${ }^{5}$ Hanya sebatas anjuran yaitu: Fatwa MUI No 52010 dengan redaksi: "Kiblat umat Islam Indonesia adalah menghadap kebarat laut dengan posisi bervariasi sesuai dengan letak kawasan masing-masing." Ditetapkan 1 Juli 2010 bertepatan 18 Rajab 1431 H. Fatwa ini dikeluarkan karena diktum fatwa No. 03 bagian ketentuan hukum No. 03 yang memunculkan pertanyaan di masyarakat, yang bisa menimbulkan kesimpangsiuran penafsiran serta pertanyaan mengenai keabsahan salat sehingga pengeluaran fatwa ini untuk dijadikan pedoman bagi masyarakat. Lihat, Majelis Ulama Indonesia, Himpunan Fatwa Majelis Ulama Indonesia, Fatwa Terbaru 2010, Arah Kiblat (Jakarta: Majelis Ulama Indonesia, 2010), h. 1.

${ }^{6}$ David A. King, Astronomy in the Service ofIslam, Chapter IX (Great Britain: Variorum Collected Studies Series, 1993), h. 1.

${ }^{7}$ Secara etimologi, kata "kiblat" berasal dari kata Arab al-qiblah (القبلة) yang secara harfiah berarti arah (al-jihah) (Manzur, t.t.:72), Ahmad Warson Munawir, al-Munawir Kamus ArabIndonesia (Surabaya: Pustaka Progressif, 1997), h. 1087-1088.
} 


\section{Metodologi}

Jenis penelitian adalah field research (lapangan) yang berlokasi di Kecamatan Tanete Riattang Barat, khususnya masjid-masjid yang ada di wilayah Kecamatan Tanete Riattang Barat, Kabupaten Bone. Penentuan lokasi menggunakan metode random sampling. Masjid yang dijadikan sampel adalah masjid yang sering dijadikan patokan arah kiblatnya oleh masjid yang lain, dengan pemilihan lokasi penelitian tersebut, dimaksudkan untuk mewakili tingkat keakuratan arah kiblat masjid yang berada di Kecamatan Tanete Riattang Barat, Kabupaten Bone.

Penelitian ini bersifat kualitatif, yakni memberikan ulasan pendapat atau kajian teoritis; seperti menggunakan rumus-rumus trigonometri yang diperlukan dalam penentuan arah kiblat, dan menggunakan teori bayang-bayang matahari serta relevansinya dengan kenyataan di lapangan.

Teknik pengumpulan data dalam penelitian ini adalah wawancara narasumber, obsevasi lapangan (pengukuran arah kiblat), serta dokumentasi. Dalam mengolah data, menggunakan analisis deduktif yang menarik kesimpulan umum dari data khusus dari tiap masjid yang telah diteliti.

\section{Pembahasan}

\section{Gambaran Singkat Masjid-Masjid Kelurahan di Kecamatan Tanete Riattang Barat Kabupaten Bone.}

Masjid adalah salah satu kata diderivasi dari kata sajada dan berarti tempat sujud, tempat salat. Jadi secara semantik, masjid berarti tempat sujud (atau tempat salat). Rasulullah Saw. bersabda: "Dimana saja engkau berada, jika waktu salat tiba, dirikanlah salat, karena di situpun masjid" (HR.Muslim) ${ }^{8}$. Hadis tersebut dipahami bahwa seluruh muka bumi adalah masjid. Artinya orang yang mendirikan salat dimana saja (kecuali di beberapa tempat yang dilarang, seperti kuburan dan toilet) di muka bumi ini, sah salatnya. Akan tetapi, di samping 
pengertian semantik itu, masjid adalah sebuah bangunan, tempat ibadah umat Islam, yang digunakan terutama sebagai tempat dilangsungkannya salat jamaah. ${ }^{9}$

Gambaran singkat masjid-masjid kelurahan di Kecamatan Tanete Riattang Barat, Kabupaten Bone adalah sebagai berikut:

a. Masjid Jami’ Miftahul Khair

Masjid Miftahul Khair mula-mula dibangun pada tahun 1979, bangunan ini berdiri di atas tanah wakaf milik H. Bungko, H. Abd.Gani, dan H. Khaeruddin dengan luas $1.293 \mathrm{~m}^{2}$ yang terletak di kelurahan Macege. Masjid ini dibangun oleh H. A. Sulam yang pendanaannya bersumber dari swadaya masyarakat. Seiring perkembangan zaman, masjid yang telah berumur 29 tahun ini telah mengalami 2 (dua) kali tahap renovasi yaitu pada tahun 1982 dan 1996. Pada saat penentuan arah kiblatnya dilakukan oleh KH. Muh. Rafi Sulaiman yang lazim di kenal "Petta Kalie", hingga sekarang arah kiblat masjid tersebut masih dijadikan rujukan. Sebagaimana yang dikatakan pengurus bahwa masjid ini paling tepat arah kiblatnya. ${ }^{10}$

b. Masjid Agung Assalam/Al- Markas Al- Ma'arif

Masjid Agung Assalam/Al- Markas Al- Ma'arif mula-mula dibangun pada tahun 1980 yang terletak di kelurahan Macanang, Peletakan batu pertama bangunan ini dilakukan oleh PB. Harahap yang pada saat itu menjabat sebagai bupati Bone. Bangunan masjid ini berdiri di atas sawah yang telah dibebaskan pemerintah pada saat itu.

Sumber dana pembangunan masjid ini berasal dari swadaya masyarakat dengan jumlah taksiran sekitar 1,5 miliar serta ditambah sokongan dana dari Presiden Republik Indonesia Mayjen TNI. Soeharto pada saat itu sekitar Rp. 150.000.000,-(Seratus lima puluh juta rupiah), Arsitektur bangunan ini di gambar oleh mahasiswa UNHAS, serta penentuan arah kiblat masjid pada saat itu dilakukan oleh: H. Abd. Azis (Kepala Bagian Pembangunan); H. Abd. Rauf

\footnotetext{
${ }^{9}$ Abdul Azis Dahlan, dkk., Ensiklopedia Hukum Islam, Jilid 6 (Cet. I; Jakarta: PT. Ichtiar Baru Van Hoeve, 1996), h.1119

${ }^{10}$ H. A. Renreng Mappa, Pengurus Masjid Miftahul Khair,’Wawancara”, Watampone, Kecamatan Tanete Riattang Barat, Tanggal 3 September 2008.
} 
(Mantan Kepala PU daerah Kab. Bone). Mereka menentukan arah kiblat dengan menggunakan kompas kiblat sesuai buku pedoman kompas. ${ }^{11}$

c. Masjid Hikmah

Masjid Hikmah terletak di Kelurahan Jeppe'e mengalami 2 (dua) tahap pembangunan yaitu: yang pertama, pada tahun 1957 dibangun dengan ukuran $8 \mathrm{x}$ 12 oleh H. Daeng Pagiling menggunakan dana sendiri, berdiri di atas tanah wakaf milik H. Pute. Kedua, Pada tahun 1991 berdirilah masjid di atas tanah seluas $10 \mathrm{x}$ $27 \mathrm{~m}^{2}$ sampai sekarang, pada tahap pembangunan ini arah kiblatnya juga mengalami perubahan/ dilakukan pengukuran ulang oleh pengurus masjid dengan menggunakan kompas. ${ }^{12}$

d. Masjid Zabulsalam/ Subulussalam

Masjid Subulussalam terletak di kelurahan Majang Kecamatan Tanete Riattang Barat, Masjid ini dibangun pada tahun 1950 oleh masyarakat di atas tanah wakaf pemberian Alm. H. Kallabe. Menurut mereka Arah kiblat masjid tidak begitu penting yang harus pas mengarah kiblat, sebab mereka berasumsi bahwa syarat sahnya salat tergantung pada niat seseorang, itu terbukti pada penetuan arah kiblat dengan menggunakan kompas arah. ${ }^{13}$

e. Masjid al-Ashar/ al-Absar

Masjid al-Absar yang terletak di Kelurahan Bulu Tempe Cirowali. Masjid ini dibangun pada tahun 1985 atas swadaya masyarakat di atas tanah wakaf. Adapun penentuan arah kiblat masjid ini diserahkan sepenuhnya kepada ahli bangunan dalam hal ini tukang batu pada saat itu menggunakan kompas. ${ }^{14}$

f. Masjid Babul Khaer

Masjid Babul Khaer terletak di kelurahan Polewali Boda. Masjid ini mulai dibangun pada tahun 1970 kemudian diresmikan pada tahun 1987 di atas tanah negara oleh Malla Haddade sekeluarga selaku sekertaris desa pada saat itu,

\footnotetext{
${ }^{11}$ H. Abd. Rauf, Mantan Kepala PU Daerah Kabupaten Bone, "Wawancara", Watampone, Kecamatan Tanete Riattang Barat, Tanggal 15 September 2008

${ }^{12}$ H. A. Mappasoro, Sekretaris Masjid Hikmah, "Wawancara", Watampone, Kecamatan Tanete Riattang Barat, Tanggal 13 September 2008.

${ }^{13}$ H. Ibnu Hajar, Pengurus Masjid Subulussalam, "Wawancara”, Watampone, Kecamatan Tanete Riattang Barat, Tanggal 2 September 2008.

${ }^{14}$ H. Muh. Sarji, Pengurus Masjid Al- Absar, "Wawancara", Watampone, Kecamatan Tanete Riattang Barat, Tanggal 23 Agustus 2008.
} 
adapun penentuan arah kiblat masjid ini diserahkan sepenuhnya kepada Pak Untung selaku pegawai PU pada saat itu menggunakan kompas. ${ }^{15}$

g. Masjid Makshadul Khaer

Masjid Makshadul Khaer terletak di Kelurahan Watang Palakka Attang Pasareng. Dibangun pada tahun1930 di atas tanah wakaf berukuran 40 x $50 \mathrm{~m}^{2}$, serta telah mengalami 4 (empat) kali tahap renovasi, yang pertama terbuat dari daun "rapiah" berlantaikan tanah kemudian menjadi permanen hingga sekarang murni swadaya masyarakat, sedangkan penentuan arah kiblatnya diserahkan pada petuah adat yang mengacu pada sinar matahari. ${ }^{16}$

h. Masjid Jami’ Az-Zikra

Masjid Jami’ Az-Zikra terletak di Kelurahan Macanang, Jl. Letjen. MT. Haryono, Pabbacue. Dibangun pada tahun 1942. Masjid ini dibangun di atas tanah wakaf berukuran $18 \times 22 \mathrm{~m}^{2}$, telah mengalami 3 (tiga) kali tahap renovasi, di antaranya: pertama: Terbuat dari daun "rapiah", masyarakat setempat menyebutnya dengan istilah "langkara-langkara" (rumah-rumah), kemudian dibangun permanen hingga sekarang. Pengukuran arah kiblat masjid ini ditentukan oleh KH. Rafi Sulaiman, masyarakat menyebutnya dengan sebutan "petta kalie", akan tetapi telah dilakukan pengukuran ulang oleh pihak STAIN Watampone. ${ }^{17}$

\section{Akurasi Arah Kiblat Masjid di Kecamatan Tanete Riattang Barat Kabupaten Bone.}

Masjid adalah tempat ibadah yang ciri khasnya mengarah ke kiblat. Kiblat adalah aspek yang sangat mendasar dalam melaksanakan ibadah salat. Sebagian besar orang membangun masjid sebarang menghadap ke barat tanpa memperhitungkan prinsip-prinsip kebenaran empirisnya.

\footnotetext{
${ }^{15}$ Malla Haddade, Pengurus Masjid Babul Khaer, "Wawancara", Watampone, kecamatan tanete Riattang Barat, Tanggal 28 Agustus 2008.

${ }^{16}$ Muh. Ishak Ali, Pengurus Masjid Makshadul Khair, "Wawancara", Watampone, Kecamatan Tanete Riattang Barat, tanggal 19 Agustus 2008.

${ }^{17}$ Man'nu, Pengurus Masjid Jami' Az-Zikra, "Wawancara”, Watampone, Kecamatan Tanete Riattang Barat, tanggal 23 Nopember 2008.
} 
Kiblat posisinya terletak dalam Masjidil Haram di kota Makkah AlMukarramah. Bagi orang yang salat dalam Masjidil Haram, tidak ada masalah mengenai arah kiblat, Karena langsung berhadapan dengan materialnya kiblat yaitu Ka'bah. Secara realitas, orang salat dalam Masjidil Haram mengelilingi Ka'bah atau shaf melingkar. Itu artinya, bagi tempat yang jauh seperti daerah Sulawesi-Selatan memerlukan pengukuran untuk bisa tembus pas mengarah kiblat. ${ }^{18}$

Oleh karena itu, orang yang sedang salat harus berdiri tegak lurus pada permukaan bumi yang mengarah ke pusat bumi. ${ }^{19}$ Sebagai proyeksi menghadapkan seluruh anggota badan ke arah kiblat. Orang yang sedang salat harus berdiri pada suatu tempat yang ditentukan oleh titik pusat tempat itu dan titik arah kiblat. $^{20}$

Pengukuran ini menyangkut arah kiblat, sehingga hasilnya tidak dapat di generalisasikan terhadap semua masjid yang ada di wilayah Kecamatan Tanete Riattang Barat. Setiap masjid di wilayah tersebut harus di ukur sendiri-sendiri. Secara astronomi Sulawesi Selatan terletak antara lintang $2^{0} 36^{\prime}-5^{0} 41^{\prime}$ Lintang Selatan (LS) dan bujur tempat $118^{0} 54^{\prime}-120^{\circ} 30^{\prime}$ Bujur Timur (BT). Sementara lintang dan bujur Ka’bah yaitu 21 ${ }^{\circ} 25^{\prime} 21.05^{\prime \prime}$ Lintang Utara (LU) dan 3949'34.27" Bujur Timur (BT). ${ }^{21}$

Tabel 1.1.

Letak Lintang dan Bujur masjid di Kec.T. R. Barat/Kabupaten Bone.

\begin{tabular}{ccccc}
\hline No. & Kelurahan & Nama Masjid & Lintang & Bujur \\
\hline 1. & Macege & Masjid Jami' Miftahul Khaer & $04^{0} 33^{\prime} 1.29^{\prime \prime}$ & $120^{\circ} 18^{\prime} 55.65^{\prime \prime}$ \\
\hline 2. & Macanang & $\begin{array}{c}\text { Masjid Agung Assalam/ } \\
\text { Markas Al-Ma'arif }\end{array}$ & $\begin{array}{c}04^{0} \\
32^{\prime} 27.12^{\prime \prime}\end{array}$ & $120^{\circ} 18^{\prime} 22,5^{\prime \prime}$ \\
\hline
\end{tabular}

${ }^{18}$ Tim Hisab Rukyat IAIN Alauddin Makassar di Dukung oleh Biro KAPP SUL-SEL, Arah Kiblat Masjid Ibukota Kabupaten/ Kota di Sulawesi Selatan (Makassar: Lamacca Press, 2002), h. 32-33.

${ }^{19}$ Sa'adoededdin Djambek, Arah Qiblat dan Cara Menghitungnya dengan Jalan Ilmu Ukur Segitiga Bola (Cet. II; Jakarta: PT. Tinta Mas Indonesia, 2004), h. 18.

${ }^{20}$ Tim Hisab Rukyat IAIN Alauddin Makassar di Dukung oleh Biro KAPP SUL-SEL, Arah Kiblat Masjid Ibukota Kabupaten/ Kota di Sulawesi Selatan (Makassar: Lamacca Press, 2002), h. 32-33.

${ }^{21}$ Penentuan koordinat Ka'bah menggunakan aplikasi Google Earth Pro 7.3.2.5776 (64bit) versi online, diakses Kamis 27 Juni 2019 pukul 08.30 wita. 
Andi Jusran Kasim:

"Analisis Keakuratan Arah Kiblat Masjid di Kecamatan Tanete Riattang Barat Kabupaten Bone"

\begin{tabular}{lcccc}
\hline 3. & Jeppe'e & Masjid Hikmah & $\begin{array}{c}04^{0} \\
32^{\prime} 36.20^{\prime \prime}\end{array}$ & $120^{\circ} 19^{\prime} 26.86^{\prime \prime}$ \\
\hline 4. & Majang & Masjid Subulussalam & $\begin{array}{c}04^{0} \\
33^{\prime} 41.86^{\prime \prime}\end{array}$ & $120^{\circ} 17^{\prime} 58.18^{\prime \prime}$ \\
\hline 5. & Bulu Tempe & Masjid Al- Absar & $04^{0} 32^{\prime} 17.83^{\prime \prime}$ & $120^{0} 16^{\prime} 49.19^{\prime \prime}$ \\
\hline 6. & Polewali & Masjid Babul Khaer & $\begin{array}{c}04^{0} \\
29^{\prime} 25.20^{\prime \prime}\end{array}$ & $120^{0} 18^{\prime} 18.16^{\prime \prime}$ \\
\hline 7. & Watang Palakka & Masjid Makshadul Khaer & $04^{0} 31^{\prime} 52.81^{\prime \prime}$ & $120^{0} 19^{\prime} 23,66^{\prime \prime}$ \\
\hline 8. & Macanang & Masjid Jami' Az-Zikra & $04^{0} 32^{\prime} 22.62^{\prime \prime}$ & $120^{0} 18^{\prime} 1.94^{\prime \prime}$ \\
\hline Sumber : GPS $^{22}$ & & &
\end{tabular}

Kemelencengan arah masjid ke kiblat, terdapat 2 (dua) kemungkinan yaitu mengarah ke sebelah kiri (barat) atau di sebelah kanan (barat laut). Masjid yang mengarah barat artinya masjid tersebut mengarah ke sebelah selatan Masjidil Haram, begitupun sebaliknya masjid yang mengarah ke sebelah barat laut berarti arah masjid tersebut mengarah di sebelah utara Masjidil Haram.

Hasil pengukuran arah kiblat masjid di Kecamatan Tanete Riattang Barat, maka hasilnya dapat diketahui sebagai berikut:

a. Masjid Jami’ Miftahul Khaer, Kelurahan Macege Bottoe

Azimuth arah kiblat masjid Jami' Miftahul Khair adalah sebesar $292^{0} 17^{\prime} 11,03$ ”. Hasil penelitian di lapangan, diperoleh azimuth kiblat masjid Jami' Miftahul Khaer sebesar $306^{0} 17^{\prime} 11,03^{\prime \prime}$ sebagaimana diketahui azimuth kiblat masjid tersebut sebesar $292^{\circ}$, maka arah kiblat masjid tersebut harus bergeser ke kiri (dikurang) $14^{0}$ utara ke barat, dikarenakan arah kiblat masjid tersebut mengarah ke negara Pakistan dan Iran. ${ }^{23}$ Sekarang kiblat masjid tersebut telah diubah (diukur ulang) oleh tim STAIN Watampone, pada hari Jumat, 21 april 2017 bertepatan 24 Rajab $1438 \mathrm{H}$. bersama panitia masjid, pihak dari Kementerian Agama, dengan mengubah shaff di dalam masjid tersebut sehingga masjid tersebut telah mengarah ke arah kiblat semestinya (Masjidil Haram).

b. Masjid Agung Assalam/ Markas al-Ma'arif Kabupaten Bone

Azimuth arah kiblat masjid Markas al-Ma'arif Kabupaten Bone adalah sebesar $292^{0} 16^{\prime} 41,03$ ”. Hasil penelitian di lapangan, diperoleh azimuth kiblat

${ }^{22}$ GPS (Global Position System) seri Garmin GPSMap 64ST Handheld GPS.

${ }^{23}$ Pengecekan arah masjid menggunakan Google Earth Pro Google Earth Pro 7.3.2.5776 (64-bit) versi online, Senin 1 Juli 2019 pukul 09.20wita. 
masjid Markas al-Ma'arif Kabupaten Bone sebesar 280¹6'41,03”, sebagaimana diketahui azimuth kiblat masjid tersebut sebesar $292^{\circ}$, maka arah kiblat masjid tersebut haruslah bergeser ke kanan (ditambah) $12^{0}$ Barat-Utara, dikarenakan arah kiblat masjid tersebut mengarah ke Benua Afrika tepatnya mengarah ke negara Somalia dan Ethopia. ${ }^{24}$ Sekarang kiblat masjid tersebut telah diubah (diukur ulang) oleh tim STAIN Watampone pada Jumat, 8 Januari 2016 bertepatan 27 Rabiul Awal 1437 H. bersama panitia masjid, pihak dari Kementerian Agama, dengan mengubah shaff di dalam masjid tersebut sehingga masjid tersebut telah mengarah ke arah kiblat semestinya (Masjidil Haram).

c. Masjid Hikmah, Kelurahan Jeppe'e Andalas

Azimuth arah kiblat masjid Hikmah adalah sebesar $292^{0} 17^{\prime} 04,52$ '. Dari hasil penelitian di lapangan, diperoleh azimuth kiblat masjid Hikmah sebesar $300^{0} 17^{\prime} 04,52^{\prime \prime}$, sebagaimana diketahui azimuth kiblat masjid tersebut sebesar $292^{0}$, maka arah kiblat masjid tersebut haruslah bergeser ke kiri (dikurang) $8^{0}$ Utara-Barat, dikarenakan arah kiblat masjid tersebut mengarah ke negara Quwait dan Irak. ${ }^{25}$

d. Masjid Subulussalam Kelurahan Majang

Azimuth arah kiblat masjid Subulussalam adalah sebesar $292^{0} 17^{\prime} 23,03$ ”. Hasil penelitian di lapangan, diperoleh azimuth kiblat masjid Subulussalam sebesar $317^{0} 17^{\prime} 23,03$ " sebagaimana diketahui azimuth kiblat masjid tersebut sebesar $292^{0}$, maka arah kiblat masjid tersebut haruslah bergeser ke kiri (dikurang) $25^{0}$ utara-barat, dikarenakan arah kiblat masjid tersebut mengarah ke negara Tajikistan, melewati negara Uzbekistan, dan Kazakhstan. ${ }^{26}$

e. Masjid al-Absar kelurahan Bulu Tempe Carawali

Azimuth arah kiblat masjid al-Absar adalah sebesar $292^{0} 17^{\prime} 22,03$ '. Hasil penelitian di lapangan, diperoleh azimuth kiblat masjid al-Absar sebesar $316^{0} 17^{\prime} 22,3^{\prime}$ sebagaimana diketahui azimuth kiblat masjid tersebut sebesar $292^{0}$,

\footnotetext{
${ }^{24}$ Pengecekan arah masjid menggunakan Google Earth Pro Google Earth Pro 7.3.2.5776 (64-bit) versi online, Senin 1 Juli 2019pukul 09.00 wita.

${ }^{25}$ Pengecekan arah masjid menggunakan Google Earth Pro Google Earth Pro 7.3.2.5776 (64-bit) versi online, Selasa 2 Juli 2019 pukul 11.00 wita.

${ }^{26}$ Pengecekan arah masjid menggunakan Google Earth Pro Google Earth Pro 7.3.2.5776 (64-bit) versi online, Rabu 3 Juli 2019 pukul 10.00 wita.
} 
maka arah kiblat masjid tersebut harus bergeser ke kiri (dikurang) $24^{0}$ utara-barat, dikarenakan arah kiblat masjid tersebut mengarah ke negara Turkmenistan. ${ }^{27}$

f. Masjid Babul Khaer Kelurahan Polewali Boda

Azimuth arah kiblat masjid Babul Khaer adalah sebesar $292^{0} 16$ '51”. Dari hasil penelitian di lapangan, diperoleh azimuth kiblat masjid Babul Khaer sebesar $323^{0} 16^{\prime} 51^{\prime \prime}$ sebagaimana diketahui azimuth kiblat masjid tersebut sebesar $292^{0}$, maka arah kiblat masjid tersebut haruslah bergeser ke kanan (ditambah) $31^{0}$ utarabarat, dikarenakan arah kiblat masjid tersebut mengarah ke benua Afrika tepatnya di negara Tanzania. ${ }^{28}$

g. Masjid Makshadul Khaer Kelurahan Watang Palakka

Azimuth arah kiblat masjid Makshadul Khaer adalah sebesar $292^{0} 16$ '59,08”. Hasil penelitian di lapangan, diperoleh azimuth kiblat masjid Makshadul Khaer sebesar $302^{0} 16^{\prime} 59,08^{\prime \prime}$ sebagaimana diketahui azimuth kiblat masjid tersebut sebesar $292^{\circ}$, maka arah kiblat masjid tersebut harus bergeser ke kiri (dikurang) $10^{0}$ utara-barat, dikarenakan arah kiblat masjid tersebut mengarah ke negara Irak. ${ }^{29}$ Sekarang masjid tersebut sudah dibangun ulang (direnovasi total) kemudian arah kiblat diukur ulang oleh pihak kementerian agama Kabupaten Bone.

h. Masjid Jami’ Az-Zikra Pabbacue Kelurahan Macanang

Azimuth arah kiblat masjid Jami' Az-Zikra adalah sebesar $292^{0} 17^{\prime} 13,6$ ”'. Hasil penelitian di lapangan, diperoleh azimuth kiblat masjid Jami' Az-Zikra sebesar $292^{0}$ sebagaimana diketahui azimuth kiblat masjid tersebut sebesar $292^{0}$, maka arah kiblat masjid tersebut telah mengarah tepat ke Masjidil Haram. Sebagaimana diketahui bahwa pengukuran/ penentuanarah kiblat masjid tersebut dilakukan oleh tim hisab rukyat STAIN Watampone.

Hasil penelitian di atas, dari 8 (delapan) sampel masjid, hanya 1 (satu) bangunan awal yang mengarah tepat ke arah Masjidil Haram, 2 (dua) telah diukur/

\footnotetext{
${ }^{27}$ Pengecekan arah masjid menggunakan Google Earth Pro Google Earth Pro 7.3.2.5776 (64-bit) versi online, Rabu 3 Juli 2019 pukul 10.20 wita.

${ }^{28}$ Pengecekan arah masjid menggunakan Google Earth Pro Google Earth Pro 7.3.2.5776 (64-bit) versi online, Rabu 3 Juli 2019 pukul 10.30 wita.

${ }^{29}$ Pengecekan arah masjid menggunakan Google Earth Pro Google Earth Pro 7.3.2.5776 (64-bit) versi online, Kamis 4 Juli 2019 pukul 15.10 wita.
} 
diubah shaffnya di dalam masjid dan telah mengarah ke Masjidil Haram oleh pihak STAIN Watampone, dan 1 (satu) direnov/ dibangun ulang oleh pihak Kementerian Agama, berarti masih ada 4 masjid dari sampel yang diambil belum melakukan pengukuran kiblat/ mengubah shaffnya yang pada dasarnya belum mengarah ke arah Kiblat/ Masjidil Haram. Adapun besar sudut kemiringan arah kiblat masjid-masjid tersebut dapat di lihat pada tabel di bawah ini:

Tabel 1.2.

Tingkat Kemelencengan Arah Kiblat Masjid Kelurahan

\begin{tabular}{|c|c|c|c|}
\hline No & Nama Masjid & $\begin{array}{c}\text { Tingkat } \\
\text { Kemelencengan }\end{array}$ & Keterangan \\
\hline 1. & $\begin{array}{l}\text { Jami’ Miftahul Khaer } \\
\text { Kelurahan Macege }\end{array}$ & $14^{0} \mathrm{U}-\mathrm{B}$ & $\begin{array}{l}\text { Harus Bergeser ke kiri } \\
14^{0}(\text { Telah diukur/ diubah } \\
\text { shaff sehingga telah } \\
\text { mengarah kearah Kiblat })\end{array}$ \\
\hline 2. & $\begin{array}{l}\text { Agung Assalam/ } \\
\text { Markas al-Ma'arif }\end{array}$ & $12^{0} \mathrm{~B}-\mathrm{U}$ & $\begin{array}{l}\text { Harus bergeser ke kanan } \\
12^{0}(\text { Telah diukur/ diubah } \\
\text { shaff sehingga telah } \\
\text { mengarah kearah Kiblat) }\end{array}$ \\
\hline 3. & $\begin{array}{l}\text { Hikmah Kelurahan } \\
\text { Jeppe'e }\end{array}$ & $8^{0} \mathrm{U}-\mathrm{B}$ & Harus Bergeser ke kiri $8^{0}$ \\
\hline 4. & $\begin{array}{c}\text { Subulussalam Kelurahan } \\
\text { Majang }\end{array}$ & $25^{0} \mathrm{U}-\mathrm{B}$ & Harus Bergeser ke kiri $25^{0}$ \\
\hline 5. & $\begin{array}{c}\text { Al-Absar Kelurahan Bulu } \\
\text { Tempe }\end{array}$ & $24^{0} \mathrm{U}-\mathrm{B}$ & Harus bergeser ke kiri $24^{0}$ \\
\hline 6. & $\begin{array}{l}\text { Babul Khaer Kelurahan } \\
\text { Polewali }\end{array}$ & $31^{0} \mathrm{~S}-\mathrm{U}$ & $\begin{array}{l}\text { Harus bergeser ke kanan } \\
31^{0}\end{array}$ \\
\hline 7. & $\begin{array}{c}\text { Makshadul Khaer } \\
\text { Kelurahan Watang } \\
\text { Palakka }\end{array}$ & $10^{0} \mathrm{U}-\mathrm{B}$ & $\begin{array}{l}\text { Harus bergeser ke kiri } \\
10^{0}(\text { Telah diukur/ } \\
\text { dibangun ulang oleh pihak } \\
\text { Kementerian Agama })\end{array}$ \\
\hline 8. & $\begin{array}{c}\text { Jami’ Az-Zikra } \\
\text { Kelurahan Macanang }\end{array}$ & Relevan & $\begin{array}{l}\text { Telah mengarah ke Kiblat } \\
\text { (Masjidil Haram) }\end{array}$ \\
\hline
\end{tabular}

Tabel 1.2 tersebut, diketahui bahwa tingkat selisih arah kiblat antar masjid tidak sama, dikemukakan bahwa kemelencengan arah kiblat masjid mulai dari yang terkecil sebesar $8^{0}$ hingga yang terbesar mencapai $31^{\circ}$. Ditemukan 2 kategori masjid, pertama: 5 (lima) masjid melenceng di sebelah utara titik sebenarnya, 
besarnya sampai $25^{\circ}$, kedua: 2 (dua) masjid melenceng di sebelah Selatan arah sebenarnya, besar melencengnya sampai $31^{0}$.

Menurut hasil penelitian arah kiblat 1990, Arah masjid yang tidak tepat dapat diterima sebagai hujjah apabila tidak melebihi $5^{0}$ (Tim Peneliti Fakultas Syariah, 1990). Tentu saja alternatif ini tidak sesuai dengan kaidah astronomi ${ }^{30}$, terlebih lagi jika dihubungkan dengan teori lintang dan bujur. Apabila dihubungkan dengan teori agama yang menyatakan bahwa bagi orang yang jauh dari Makkah arah kiblatnya adalah kota Makkah, Sementara batas kota Makkah yang sebelah Selatannya Makkah hanya sekitar $70 \mathrm{~km}$ dan sebelah utaranya sekitar $450 \mathrm{~km}$, lantas selisih $1^{0}$ bernilai jarak $110 \mathrm{~km}$, maka dipastikan batas toleransi hanya setengah derajat yang di sebelah selatan titik sebenarnya dan $4,5^{\circ}$ yang di sebelah utara titik sebenarnya. Ini pun berlaku apabila hasil pengukuran dilakukan secara cermat dan akurat. ${ }^{31}$

Oleh karena itu, harus berhati-hati dalam melakukan batas toleransi, bahkan kalau perlu tidak menggunakan batas toleransi karena arah kiblat dapat diketahui dengan pasti apa bila dilakukan dengan menggunakan peralatan yang memenuhi syarat dengan bantuan sinar matahari maka hasilnya dapat diketahui serta sangat efektif.

\section{Penutup}

Berdasarkan analisis data di lapangan dan teori-teori yang dijadikan landasan dalam pembahasan tentang Arah kiblat ditarik simpulan:

1. Kiblat adalah patokan arah umat muslim dalam melaksanakan ibadah. Kiblat sama halnya menghadap ke Baitullah, menghadap ke Baitullah hukumnya wajib bagi setiap muslim dalam melaksanakan salat di dalam Masjidil Haram dan Masjidil Haram kiblat bagi umat diluar kota Makkah. Sudah barang tentu bagi orang yang langsung dapat melihat Ka'bah baginya berusaha agar

${ }^{30}$ Astronomi adalah ilmu pengetahuan yang mempelajari benda-benda langit dan alam semesta secara umum. Muhyiddin Khazin, Kamus Ilmu Falak (Jogjakarta: BuanaPustaka, 2005), h. 9. Lihat pula Iratus Radiman, et. al, Ensiklopedi singkat astronomi dan ilmu yang bertautan (Bandung: Penerbit ITB, 1980), h. 6.

${ }^{31}$ Tim Hisab Rukyat IAIN Alauddin Makassar di Dukung Oleh Biro KAPP Sul-Sel, Arah Kiblat Masjid Ibukota Kabupaten/ Kota di Sulawesi Selatan (Makassar: Lamacca Press, 2002), h. 51. 
menghadap persis ke Baitullah, sedangkan orang yang tidak dapat melihatnya secara langsung Baitullah, karena terhalang tempat atau jarak yang terlalu jauh, baginya hanya wajib menghadap ke arah Masjidil Haram.

2. Tujuh masjid Kelurahan di Kecamatan Tanete Riattang Barat ditambah 1 (satu) masjid Kabupaten, diperoleh hasil bahwa hanya satu masjid dengan bangunan awal yang mengarah ke kiblat, masjid tersebut ialah masjid Jami Az-Zikra di Kelurahan Macanang yang telah diukur ulang oleh Tim Hisab Rukyat STAIN Watampone dan Masjid Markaz al-Ma'arif dan masjid Jami' Miftahul Khaer kelurahan Macege juga telah mengarah setelah diubah bentuk shaff di dalam masjid serta masjid Makshadul Khaer Kelurahan Watang Palakka yang telah dibangun ulang dan diukur ulang oleh pihak Kementerian Agama, selebihnya belum mengarah ke arah Kiblat yang sebenarnya, adapun kemelencengan arah kiblatnya bervariasi antara: $8^{0}-31^{0}$. Kalau dikaitkan dengan ilmu astronomi bahwa batas kota Makkah di sebelah selatan hanya sekitar $70 \mathrm{~km}$ dan sebelah utaranya sekitar $450 \mathrm{~km}$, lantas selisih $1^{0}$ bernilai jarak $110 \mathrm{~km}$, maka dalam mencapai keutamaan amal serta keseragaman arah dalam beribadah telah jauh dari apa yang di harapkan. 


\section{Daftar Pustaka}

A. King, David. Astronomy in the Service of Islam. Chapter IX, Great Britain: Variorum Collected Studies Series, 1993.

Abd Salam. Ilmu Falak Praktis (Waktu Salat, Arah Kiblat, dan Kalender Hijriah). (Buku Perkuliahan Program S-1 Program Studi Hukum Ekonomi Syariah (Muamalah) Fakultas Syari'ah dan Hukum UIN Sunan Ampel Surabaya, 2007.

Abdul Azis Dahlan, dkk. Ensiklopedia Hukum Islam. Jakarta: PT. Ichtiar Baru Van Hoeve, 1996.

Djambek, Sa'adoededdin. Arah Qiblat dan Cara Menghitungnya Dengan Jalan Ilmu Ukur Segitiga Bola, Jakarta: PT. Tinta Mas Indonesia, 2004.

Fatwa MajelisUlama Indonesia, No 5, Tahun 2010.

http://repository.umy.ac.id/bitstream/handle/123456789/16600/Bab\%20I.pdf?sequ ence $=2 \&$ isAllowed $=\mathrm{y}$

Ibnu Katsir. Tafsir Al-Qur'an Al-Adzim, JuzI,tt.

Ibnu Rusyd. Bidayat al-Mujtahid wa Nihayat al-Muqtashid. Beirut: Dar al-Fikri.

Kementerian Agama Republik Indonesia, Direktorat Jenderal Bimbingan Masyarakat Islam Direktorat Urusan Agama Islam dan Pembinaan Syariah, Alquran dan Terjemahannya. Jakarta: PT. SinergiPustaka Indonesia, Tahun 2012.

Khazin, Muhyiddin. Kamus Ilmu Falak. Jogjakarta: Buana Pustaka, 2005.

Lidwa Pusaka i-Software-Kitab 9 Imam Hadist; Hadis Bukhari, Bab: Salat, hadist no. 394. Diakses 2 juli 2019.

Majelis Ulama Indonesia. Himpunan Fatwa Majelis Ulama Indonesia, Fatwa Terbaru 2010, Arah Kiblat. Jakarta: MajelisUlama Indonesia, 2010.

Al-Qurthubi, Al-Jami' li Ahkam Alquran.

Radiman, Iratus, et. al. Ensiklopedi Singkat Astronomi dan Ilmu Yang Bertautan, Bandung: Penerbit ITB, 1980.

Tim Hisab Rukyat IAIN Alauddin Makassar di dukung oleh Biro KAPP SULSEL. Arah Kiblat Masjid Ibukota Kabupaten/ Kota di Sulawesi-Selatan, Makassar: Lamacca Press, 2002.

Warson Munawir, Ahmad. al-Munawir Kamus Arab Indonesia. Surabaya: Pustaka Progressif, 1997.

GPS (Global Position System) seri Garmin GPSMap 64ST Handheld GPS.

Google Earth Pro Google Earth Pro 7.3.2.5776 (64-bit) versi online. 